\title{
An Empirical Research on Influence of Quality in Product Purchase
}

\author{
K.S.Aishwarya Lakshmi, Aruna A.R
}

\begin{abstract}
Customers perceive that quality is a significant property in products and providers perceive that quality can be a significant differentiator between their own contributions and those contenders. The main objective of the study if to identify whether the quality has bearing on purchase of products and reputation of the company. The data for the study is collected through the primary and secondary sources. . Questionnaire is used as the primary data collection and the article, journals, reports, newsletter are considered as the secondary sources .Convenience sampling method is used and the sample size is 926. The data collected are analyzed using SPSS. From analysis, it was found that quality plays a key role in product purchase and also maintaining company reputation. Also, it is found that there is a significant difference between the reputation of a company depends on the quality of the product and the educational qualification and there is a significant association between the person who is responsible for the defect of quality and age. Thus, quality products make a significant commitment to long haul income and benefit
\end{abstract}

KEYWORDS: Quality, Product, Manufacturing, Customers, Perceptions

\section{INTRODUCTION}

Quality is a conditional, and fairly emotional characteristic and the perception of quality vary between various individuals. Consumers From the producer's point of view, consumers look for particular aspects and producers ensure that they deliver the same. Makers may measure the how far the product conforms to the quality, or degree to which the product/administration was delivered effectively. Bolster staff may gauge quality in the degree that a product is dependable, viable, or sustainable. There are numerous parts of quality in a business setting, however essential is the thought the business produces something, regardless of whether it be a physical decent or a specific administration. The developing significance of internet based life implies that customers has great impact on quality and analysis of product quality on discussions, product audit locales and interpersonal interaction destinations. A solid notoriety for quality can be a significant differentiator in business sectors that are aggressive. Low quality or product disappointment that outcomes in a product review battle can prompt negative exposure and harm your notoriety. Adherence to a perceived quality standard might be fundamental for managing certain customers or agreeing to legislation. Accredited quality control frameworks assume an essential job in consenting to those benchmarks. Accreditation can

Revised Manuscript Received on 14, October 2019.

K.S.Aishwarya Lakshmi, B.B.A LLB(HONS), Saveetha School of Law, Saveetha Institute Of Medical And Technical Sciences(SIMATS), Chennai, Tamilnadu, India.(E-mail: patelnirzari84@gmail.com)

Ms, Aruna A.R, Assistant professor, Department of Management, Saveetha Institute Of Medical And Technical Sciences(SIMATS), Chennai, Tamilnadu, India.(E-mail: arunasathis@gmail.com) likewise enable you to win new customers or enter new markets by giving prospects autonomous affirmation of your organization's capacity to supply quality products. The main aim of the study is to understand the influence of quality on product purchase.

\section{OBJECTIVES}

- To find whether the reputation of a company depends on the quality of the product.

- To understand the influence of quality on product purchase.

- To identify the person who is responsible for the defect of quality.

\section{REVIEW OF LITERATURE}

Sen (2017) Customers perceive that quality is a significant property in products and administrations, and providers perceive that quality can be a significant differentiator between their own contributions and those of contenders (the quality hole). Duncanson et al.(2019)

These products and additionally administrations and how they are created include numerous kinds of procedures, methods, gear, work force, and ventures, which all fall under the quality umbrella. Duncanson et al.; Martynova (2016) Key parts of quality and how it's diffused all through the business are established in the idea of quality administration. While quality administration and its fundamentals are generally late wonders, the possibility of quality in business isn't new. "CHAPTER III. TRANSPORTATION COSTS AND MANUFACTURING INDUSTRIES"; Secretariat and Commonwealth Secretariat (2012)

In the previous two decades this quality hole has been step by step diminishing between aggressive products and administrations. This is halfway because of the contracting (likewise called redistributing) of manufacturing to nations like China and India, also internationalization of exchange and rivalry. Shewhart(2004) These nations, among numerous others, have raised their very own principles of quality so as to satisfy universal guidelines and customer demands.Traditionally, quality goes about as one of five tasks/venture execution targets directed by activities the board strategy. Jhang (2000) Tasks the executives, by definition, centers around the best and productive ways for making and conveying a decent or administration that fulfills customer needs and desires. In that capacity, its connections to quality are apparent. Shewhart; Kenyon and Sen (2002) The push to incorporate the idea of quality

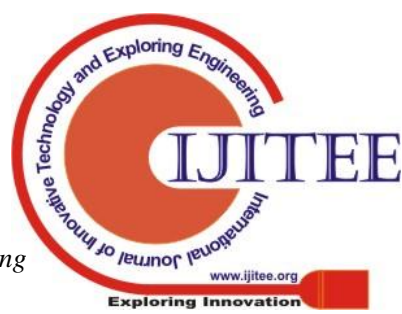


into the elements of the administration business takes a somewhat extraordinary way from manufacturing. Manyeula et al (2000). Different impediments incorporate administration's perceptions not lining up with customer desires because of absence of correspondence and statistical surveying and inappropriate or absence of conveyance of aptitude based information to personnel. Xu et al.(2017) Like manufacturing, customer desires are key in the administration business, however the degree with which the administration interfaces with the customer unquestionably shapes apparent administration quality. Okada (2012) Perceptions, for example, being trustworthy, responsive, understanding, capable, and clean (which are hard to depict substantially) may drive administration quality, somewhat as opposed to factors that drive estimation of manufacturing quality.

\section{RESEARCH METHODOLOGY}

The current study based on the descriptive research. Convenience sampling method is used(Non-probability sampling). The data is collected through the primary and secondary sources. . Questionnaire is used as for collection of primary data and the article, journals, reports, newsletter are considered as the secondary sources. The sample size is 926.. The analysis is done by using SPSS 21 version . Statistical tools used for analysis are Chi-Square and ANOVA. Dependent variables used are reputation of a company depends on the quality of the product, influence of quality on product purchase and authority responsible in case of defect in quality. Independent variables used are age and educational qualification

\section{ANALYSIS AND DISCUSSION}

NULL HYPOTHESIS: There is no significant difference of quality of product determines company reputation between educational qualification groups.

ALTERNATE HYPOTHESIS: There is significant difference of quality of product determines company reputation between educational qualification groups.

\section{ANOVA}

Table 1 - . Reputation of a company depends on the quality of the product produced

\begin{tabular}{|l|l|l|l|l|l|}
\hline & $\begin{array}{l}\text { Sum of } \\
\text { Squares }\end{array}$ & df & $\begin{array}{l}\text { Mean } \\
\text { Square }\end{array}$ & F & Sig. \\
\hline $\begin{array}{l}\text { Between } \\
\text { Groups }\end{array}$ & 36.252 & 3 & 12.084 & 9.739 & .000 \\
$\begin{array}{l}\text { Within } \\
\text { Groups } \\
\text { Total }\end{array}$ & 1144.000 & 922 & 1.241 & & \\
\hline
\end{tabular}

\section{INTERPRETATION}

It was found that $\mathrm{p}$ value is less than 0.05 , which shows that the null hypothesis is rejected. Therefore there is a significant difference between the reputation of a company depends on the quality of the product and the educational qualification. Hence educational qualification of respondent influences the perception that quality impacts company reputation.

\section{HYPOTHESIS}

NULL HYPOTHESIS: There is no significant association between the person who is responsible for the defect of quality and age.

ALTERNATE HYPOTHESIS: There is a significant association between the person who is responsible for the defect of quality and age.

Table 2: Cross Tabulation. Who is responsible for the quality defect in a product? and Age

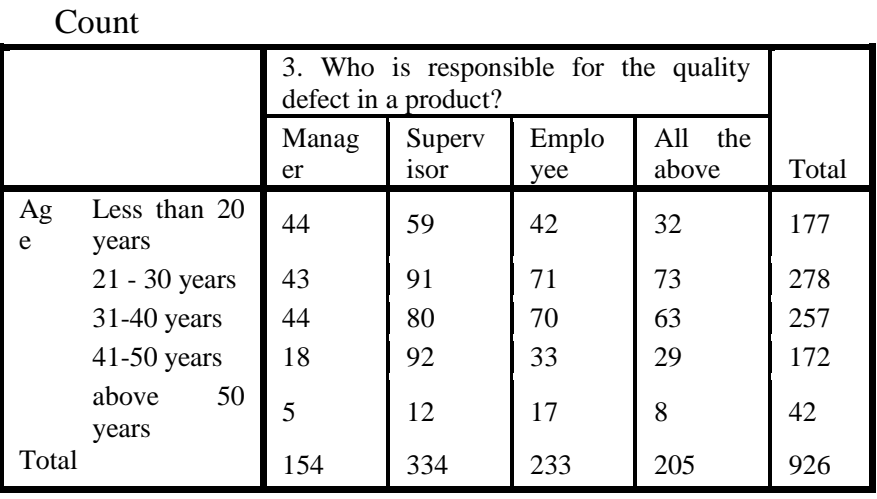

Chi-Square Tests

\begin{tabular}{|l|l|l|l|}
\hline & Value & df & $\begin{array}{l}\text { Asymptotic } \\
\text { Significance } \\
\text { (2-sided) }\end{array}$ \\
\hline $\begin{array}{l}\text { Pearson Chi-Square } \\
\text { Likelihood Ratio }\end{array}$ & $43.458^{\mathrm{a}}$ & 12 & .000 \\
Linear-by-Linear & 41.197 & 12 & .000 \\
Association & .726 & 1 & .394 \\
N of Valid Cases & 926 & & \\
\hline
\end{tabular}

a. 0 cells $(0.0 \%)$ have expected count less than 5 . The minimum expected count is 6.98 .

\section{INTERPRETATION}

Using chi square test, it was found that $\mathrm{p}$ value is less than 0.05 , which shows that the null hypothesis is rejected. Therefore there is significant association between the person who is responsible for the defect of quality and age.

\section{CONCLUSION}

Quality has an influence on the consumer buying decision. The fact remains that consumers consider quality in their buying situation. Customers perceive that quality is a significant property in products and administrations, and providers perceive that quality can be a significant differentiator between their own contributions and those of contenders. It is important to suggest that other factors influencing purchase decisions such as product value, company's image, advertisements etc should not be neglected, but should serve as accomplices in the maintenance of customer's loyalty and confidence in the industry. 


\section{REFERENCES}

1 "CHAPTER III. TRANSPORTATION COSTS AND MANUFACTURING INDUSTRIES." Location Theory and the Shoe and Leather Industries, doi:10.4159/harvard.9780674498624.c5.

2 Creese, Robert, and M. Adithan. Estimating and Costing for the Metal Manufacturing Industries. CRC Press, 1992.

3 Duncanson, L., et al. "The Importance of Consistent Global Forest Aboveground Biomass Product Validation." Surveys in Geophysics, vol. 40, no. 4, May 2019, pp. 979-99.

4 Gumprecht, R. O. Plutonium Product Quality. 1954, doi:10.2172/87792.

5 Guo, Hongye, et al. "Quality Evaluation of Based on PUFAs Using HPLC Fingerprint Techniques Combined with Chemometric Methods." Foods (Basel, Switzerland), vol. 8, no. 8, Aug. 2019, doi:10.3390/foods8080322.

6 Hansen, Teis, and Lars Winther. "Manufacturing in the Knowledge Economy: Innovation in Low-Tech Industries." Handbook of Manufacturing Industries in the World Economy, pp. 439-50, doi:10.4337/9781781003930.00040.

7 Information Technology. Software Product Quality. doi:10.3403/02304484.

8 Jhang, Kwang-Soo. Productivity Performance in Korean Manufacturing Industries. doi:10.31274/rtd-1808176600.

9 Keel, Keith. Occupational Employment in Manufacturing Industries. 1991.

10 Kenyon, George N., and Kabir C. Sen. The Perception of Quality: Mapping Product and Service Quality to Consumer Perceptions. Springer, 2014.

11 Kincade, Doris H. Sewn Product Quality: A Management Perspective. Prentice Hall, 2007.

12 Manyeula, F., et al. "Partial Replacement of Soybean Products with Canola Meal in Indigenous Chicken Diets: Size of Internal Organs, Carcass Characteristics and Breast Meat Quality." Poultry Science, Aug. 2019, doi:10.3382/ps/pez470.

13 Martynova, Olha. “Aspects Of Product Quality Control: Determination Of Quality Components And Product Quality Factor." Social and Natural Sciences Journal, vol. 2, 2011, doi:10.12955/snsj.v2i0.271.

14 Okada, Yosuke. Competition and Productivity in Japanese Manufacturing Industries. 2005 , doi:10.3386/w11540.

15 Pastor-Moreno, Guadalupe, et al. "Intimate Partner Violence During Pregnancy and Risk of Fetal and Neonatal Death: A Meta-Analysis with Socioeconomic Context Indicators." American Journal of Obstetrics and Gynecology, Aug. 2019, doi:10.1016/j.ajog.2019.07.045.

16 Secretariat, Commonwealth, and Commonwealth Secretariat. An Overview of Manufacturing Industries. 1979, doi:10.14217/9781848592889-8-en.

17 Shewhart, Walter Andrew. Economic Control of Quality of Manufactured Product. ASQ Quality Press, 1931.

18 Shimbun, Nikkan Kogyo. Poka-Yoke: Improving Product Quality by Preventing Defects. CRC Press, 1989.

$19 \mathrm{Xu}$, Wenxuan, et al. "Understanding the SpatialTemporal Patterns and Influential Factors on Air Quality Index: The Case of North China." International Journal of Environmental Research and Public Health, vol. 16 , no. 16, Aug. 2019, doi:10.3390/ijerph16162820.

20 Yadav, Vibhu, et al. "Regulatory Approval Process for Advanced Dressings in India: An Overview of Rules." Journal of Wound Care, vol. 28, no. Sup8, Aug. 2019, pp. S32-42. 